\title{
The mediating role of experiential avoidance in the relationship between Alexithymia and emotion regulation in patients with major depression disorder after traumatic brain injury
}

\author{
Mohtaram Nemattavousi ${ }^{1}$, Shiva Soltaninia ${ }^{2}$ \\ 1-Assistant Professor, Department of Psychology, South Tehran Branch, Islamic Azad University, Tehran, Iran \\ (Corresponding Author). E-mail: nemattavousei@yahoo.com \\ 2- Master of General Psychology, Department of Psychology, South Tehran Branch, Islamic Azad University, \\ Tehran, Iran.
}

Received: 09/01/2020 Accepted: 19/04/2020

\begin{abstract}
Introduction: Emotional problems are among the most common traumatic brain injury consequences that are associated with major depression after traumatic brain injury.

Aim: The aim of this study was to examine the mediating role of experiential avoidance in the relationship between alexithymia and emotion regulation in patients with major depression disorder after traumatic brain injury.

Method: This descriptive-correlational study was performed on 60 patients with traumatic brain injury diagnosed with major depression disorder and treated in Shahid Beheshti Hospital of Kashan. Data were collected using second version of the Acceptance and Action Questionnaire (Bond \& et al, 2011), Toronto Alexithymia Scale (Bagby, Parker \& Taylor, 1994) and Difficulties in Emotion Regulation scale (Gratz \& Roemer, 2004) and analysis was performed using Pearson correlation test and Celsius regression analysis.
\end{abstract}

Results: The findings of the study showed a significant relationship between alexithymia, emotion regulation and experiential avoidance $(\mathrm{P}<0.01)$ and experiential avoidance plays a role of partial interfaces in the relationship between alexithymia and difficulty in emotion regulation $(\mathrm{P}<0.05)$.

Conclusion: According to the results, change in experiential avoidance leads to a change in alexithymia and emotion regulation. This study paves the way for using experiential avoidance reducing focused interventions, including acceptance and commitment therapy in major depression disorder after traumatic brain injury.

Keywords: Experiential avoidance, Alexithymia, Emotion regulation, Traumatic brain injury

\footnotetext{
How to cite this article : Nemattavousi M, Soltaninia Sh. The mediating role of experiential avoidance in the relationship between Alexithymia and emotion regulation in patients with major depression disorder after traumatic brain injury. Shenakht Journal of Psychology and Psychiatry. 2020; 7 (2): 140-152 .URL: http://shenakht.muk.ac.ir/article-1-774-fa.pdf
}

Copyright $(\odot 2018$ the Author (s). Published by Kurdistan University of Medical Sciences. This is an open access article distributed under the terms of the Creative Commons Attribution-Non Commercial License 4.0 (CCBY-NC), where it is permissible to download, share, remix, transform, and buildup the work provided it is properly cited. The work cannot be used commercially without permission from the journal. 


\title{
نقش واسطهاى اجتناب تجربهاى در رابطه بين ناكويى هيجانى و تنظيم هيجان در بيماران

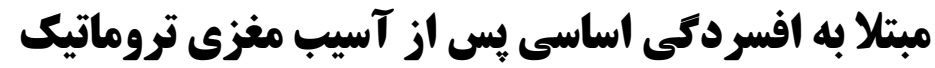

\begin{abstract}
محترم نعمت طاوسى'، شيوا سلطانى نيا'

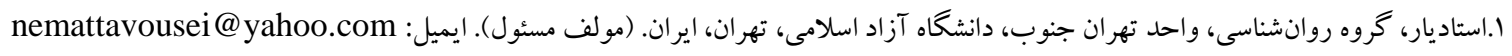

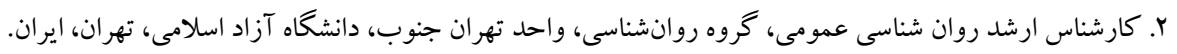

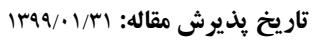

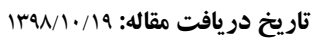

جكيده

مقدمه: مشكلات هيجانى از جمله شايع ترين بيامدهاى آسيب مغزى تروماتيك بوده كه در سببشناسى افسردگى اساسى بس از آسيب مغزى تروماتيك دخيل هستند.

هدف: اين بزوهش با هدف بررسى نقش واسطهاى اجتناب تجربهاى در رابطه بين ناگويى هيجانى و تنظيم هيجان در بيماران مبتلا به افسردگى اساسى بس از آسيب مغزى تروماتيك انجام شد.

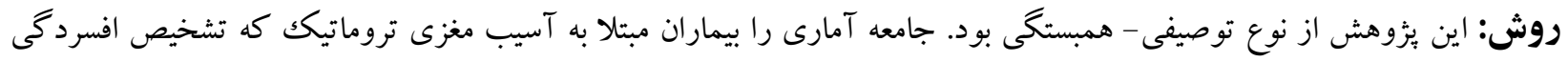

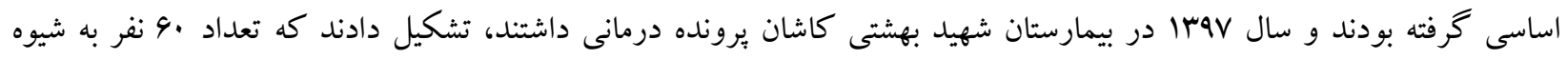

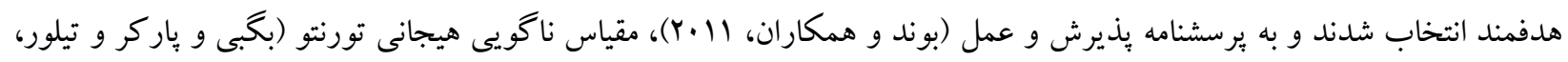

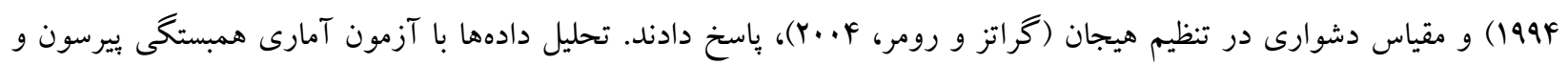
تحليل رگرسيون سلسله مراتبى بر اساس روش بارون و كنى دونى انجام شد.

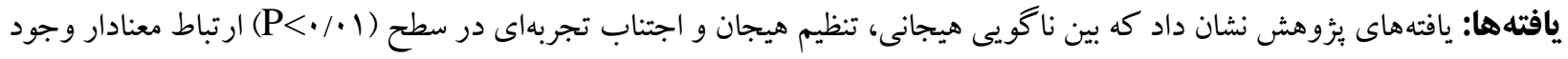

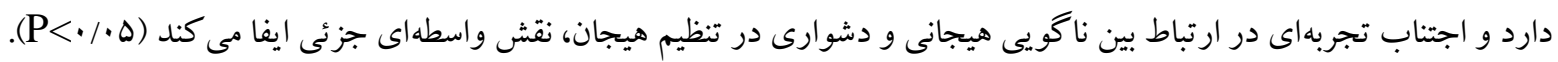
نتيجه كيرى: با توجه به نتايج به دست آمده، تغيير در اجتناب تجربهاى موجب تغيير در ناكويى هيجان و تنظيم هيجان مىشود. بدين

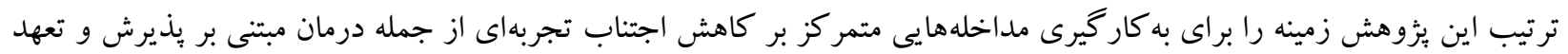

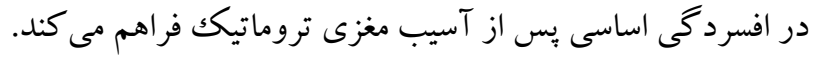
كليد وازهها: اجتناب تجربهاى، ناكويى هيجانى، تنظيم هيجان، آسيب مغزى تروماتيك 


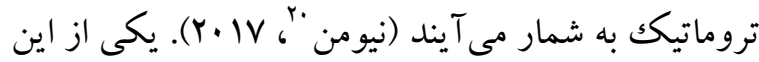

مقدمه

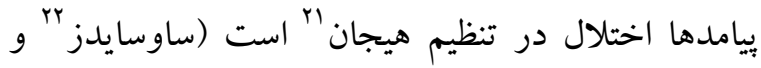

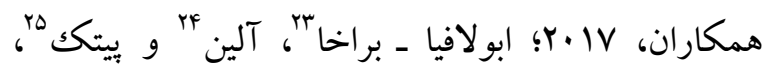

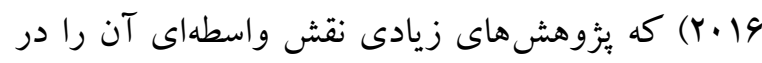

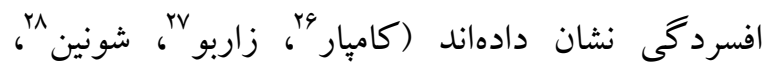

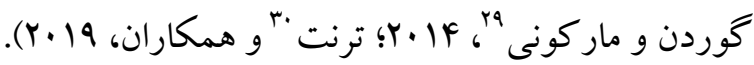
تنظيم هيجان فرآيندى است كه توسط آن، افراد

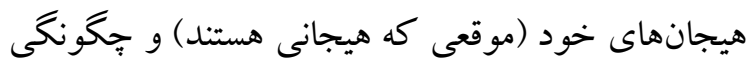
تجربه يا ابراز اين هيجانها را تحت نفوذ خود قرار

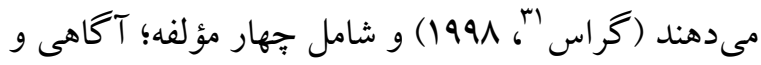
فهم از هيجانها، يذيرش هيجانها، توانايى براى كنترل رفتارهاى تكانشى و رفتار نمودن بر اساس اهداف مورد

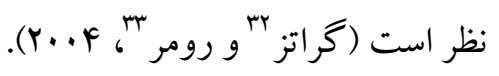
تلاشهاى بسيارى براى فهم بهتر سازههايى كه با دشوارى در تنظيم هيجان مرتبط هستند صورت گرفته به اين اميد كه مكانيزمهاى زيربنايى آن را شناسايى كرده و هدف

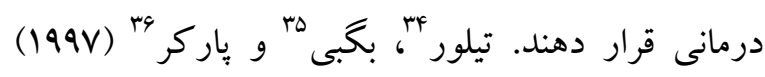

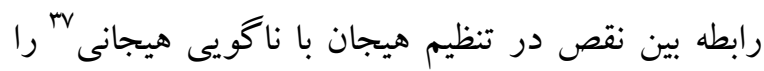
مطرح كردهاند. ناكويى هيجانى نيز از جمله مشكلات هيجانى است كه مطالعهاى زيادى رابطه آن با اختلال

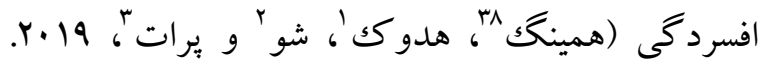

${ }^{20}$ - Neumann, D.

${ }^{21}$ - Emotion Regulation (ER)

${ }^{22}$ - Tsaousides, T.

${ }^{23}$ - Aboulafia-Brakha, T.

${ }^{24}$ - Allain, P.

${ }^{25}$ - Ptak, R.

26- Compare, A.

${ }^{27}$ - Zarbo, C.

${ }^{28}$ - Shonin, E.

${ }^{29}$ - Marconi, C.

${ }^{30}$ - Trent, E. S.

${ }^{31}$ - Gross, J. J.

${ }^{32}$ - Gratz, K. L.

${ }^{33}$ - Roemer, L.

${ }^{34}$ - Taylor, C. A.

35 - Bagby, R. M.

${ }^{36}$ - Parker, J. D. A

${ }^{37}$ - Alexithymia

${ }^{38}$ - Hemming, L.

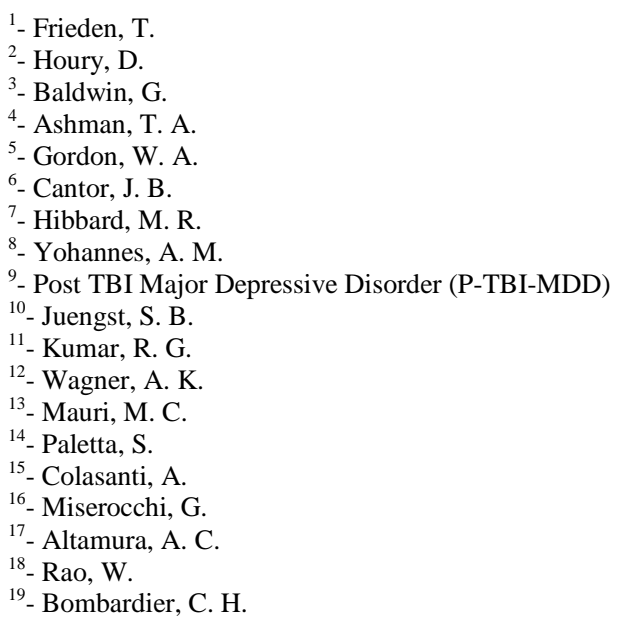


آن تأثير دارد (ونتا و همكاران، Y Y.Y). از طرفى در سببشناسى اختلال افسردگى اساسى بس از آسيب مغزى تروماتيك عوامل متعددى نقش دارند كه اين امر ضرورت كاربستهاى بالينى فراتشخيص را در اين بيماران نشان مىدهد كه در اين بين درمان مبتنى بر يذيرش و تعهل به عنوان كاربستى فرا تشخيص با تمركز بر كاهش اجتناب از طريق يذيرش، انعطافيذيرى روانشناختى را هسته اصلى درمان معرفى مى كند

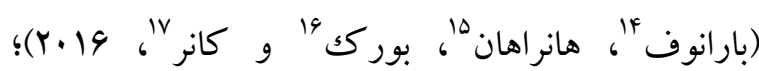
بنابراين اين يُوهش با بررسى نقش واسطهاى اجتناب

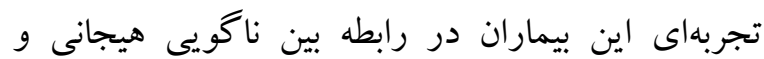
تنظيم هيجان آنها، مىتواند زمينه را براى به كارگيرى مداخلههايى متمركز بر كاهش اجتناب تجربهاى از جمله

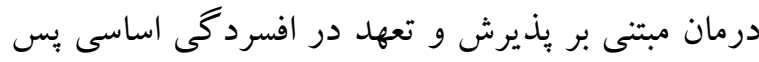
از آسيب مغزى تروماتيكك فراهم كند.

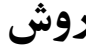

اين بزوهش از لحاظ هدف بنيادى و شيوه گردآورى دادهها از نوع توصيفى- همبستكى به شمار مىرود. جامعه آمارى اين بثزوهش بيماران مبتلا به آسيب مغزى تروماتيك بودند كه در سال Vه ا در بيمارستان شهيد بهشتى كاشان برونده درمانى داشتند. در اين ئزوهش معيارهاى ورود شامل: داشتن تشخيص افسردگى اساسى بِ از آسيب مغزى تروماتيك، ابتلا به افسردگى اساسى پِ از آسيب مغزى تروماتيك حداكثر بين يك تا جهار

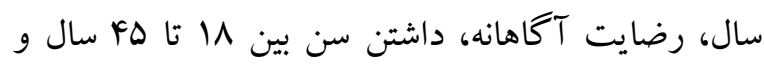
تحصيلات حداقل سيكل و معيارهاى خروج شامل:

14- Baranoff, J. A.

15 - Hanrahan, S. J.

16- Burke, A. L.

${ }^{17}$ - Connor, J. P.

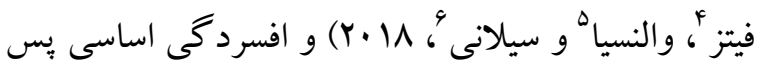
از آسيب مغزى تروماتيك را نشان دادهاند (نيومن،

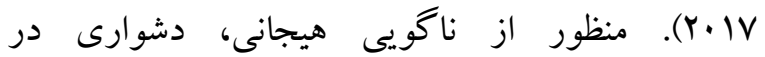
يردازششناختى اطلاعات هيجانى و اختلال در تنظيم هيجان است (بخبى و تيلور، 199V) و اصلىترين ويزگى هاى آن شامل ناتوانى در شناخت و توصيف كلامى هيجانهاى تجربه شده؛ نقص و نارسايى در تفكر عينى كه ابراز احساسها، خواستها و تمايلهايى را به

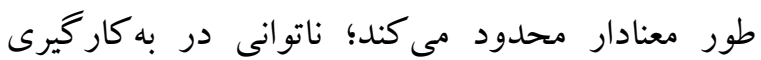
احساسها، بهعنوان علائم احتمالى مشكلات هيجانى و ناتوانى در به خاطر آوردن رؤياها است (تيلور، ياركر،

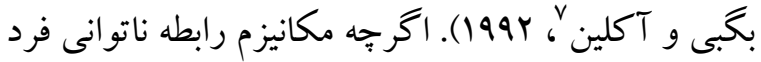
در استفاده از وازهها براى بيان هيجانهاى خود (ناگويى هيجانى) با ناتوانى در تنظيم هيجان هنوز كاملاً

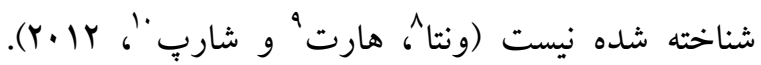
يافتها كه مبنى بر ارتباط بين ناكويى هيجانى و تنظيم هيجان است، حاكى از محتمل بودن جندين نوع رابطه

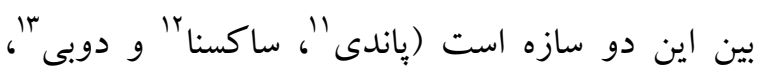
$(Y \cdot)$

بنابر آنجه ذ ذكر شد، اختلال در تنظيم هيجان يكك وضعيت بالينى عمده در افسردگى اساسى بس از آسيب مغزى تروماتيك است كه بر اساس يافتها در جوامع بالينى ديخر ناگويى هيجانى از طريق اجتناب تجربهاى بر

\footnotetext{
1. Haddock, G.

2- Shaw, J.

3 - Pratt, D

4- Fietz, J.

5 - Valencia, N.

6- Silani, G.

7- Acklin, M. W.

8 - Venta, A.

9 - Hart, J.

${ }^{10}$ - Sharp, C.

${ }^{11}$ - Pandey, R.

12 - Saxena, P.

13 - Dubey, A.
} 
معنادار آن نشاندهنده اثر واسطهاى جزئى است. براى

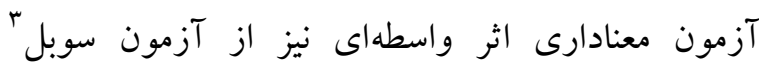

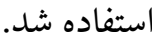

ابزار

مصاحبه بالينى: مصاحبه بالينى ساختار يافته براى راهنماى تشخيصى آمارى اختلالهاى روانى - ويرايش بنجم"

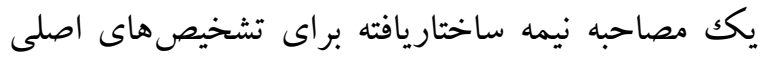
راهنماى تشخيصى آمارى اختلالهاى روانى - ويرايش

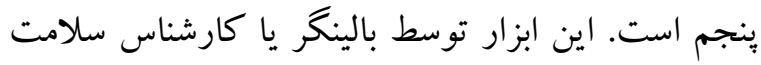
روان آموزشديده كه با معيارهاى تشخيصى و طبقهبندى اختلالها در راهنماى تشخيصى آشناست، اجرا مى گردد. جمعيت مورد مصاحبه بيماران روانيزشكى يا دجار بيمارى طبى عمومى يا افرادى كه خود را به عنوان بيمار نمىشناسند، است. يوشش تشخيصى و زبان استفاده شده اين يرسشنامه آن را براى افراد بالاى \\ سال مناسب مى كند؛ هر جند با تغيير مختصر در عبارتبندى سؤالها ممكن است بتوان از آن براى نوجو انان نيز استفاده كرد

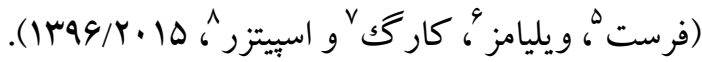
يرسشنامه اطلاعات دموكرافيك: برسشنامهاى كه محقق ساخته براى جمع آورى اطلاعات جمعيتشناختى

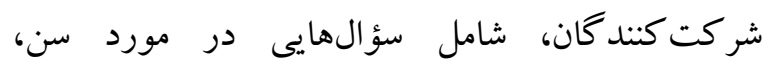
تحصيلات، تأهل، وضعيت اقتصادى و غيره.

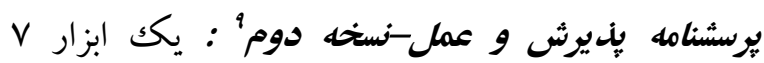

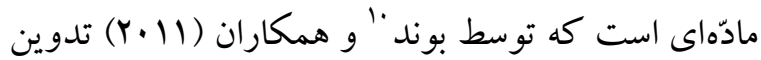
شده است. اين ابزار تكك عاملى، اجتناب از تجارب

${ }^{3}$ - Sobel Test

4- The Structured Clinical Interview for DSM-5 (SCID-5)

5 - First, M.

6- Williams, J.

7. Karg, R.

8 - Spitzer, R

9 - Acceptance and Action Questionaries-2 (AAQ-2)

${ }^{10}$ - Bond, F. W.
سوءمصرف الكل، مواد يا دارو، زوال عقل و روان آشفتگى و اختلالهاى روانى به جز افسردگى اساسى بودند. تعداد •4 نفر از بيماران مذكور كه قبل از ورود به يثزوهش طى مصاحبه بالينى توسط يكك روانشناس بالينى آموزش ديده تشخيص افسردگى اساسى را دريافت كرده بودند، براى شركت در اين بثوهش بهصورت هدفمند انتخاب شدند. هدف بيزوهش براى شركت كنند شان روشن و رضايت آكاهانه از آنها اخذ كرديد. سبس برس

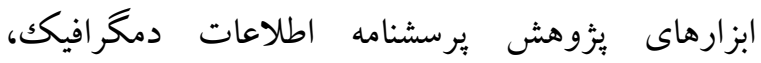
برسشنامه بذيرش و عمل_نسخه دوم، مقياس ناكويى يرون هيجانى تورنتو و مقياس دشوارى در تنظيم هيجان با ترتيبهاى تصادفى جهت بِاسخدهى در اختيار شر كت كنند كان قرار كر فتند. تجزيه و تحليل دادهها با آزمون آمارى همبستخى ييرسون براى بررسى ارتباط بين متغيرهاى يزوهش و تحليل ركرسيون سلسله مراتبى بر اساس روش بارون و كنى

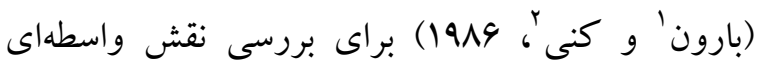
اجتناب تجربهاى در رابطه بين ناكويى هيجانى و تنظيم هيجان با استفاده از نرم افزار SPSS نسخه ه انجام شد. در روش بارون و كنى، زمانى مىتوان متغيرى را در رابطه بين دو متغير ديخر داراى نقش واسطهاى دانست كه جهار شرط در نتايج تحليل رگرسيون برقرار باشد: الف) ارتباط بين متغير مستقل و وابسته معنادار باشد؛ ب) ارتباط بين متغير مستقل و واسطهاى معنادار باشد؛ ج) يّ از ورود همزمان متغير مستقل و واسطهاى، متغير واسطهاى اثر معنادارى بر متغير وابسته داشته باشد؛ د) از دست رفتن كامل معنادارى ارتباط متغير مستقل و وابسته در معادله

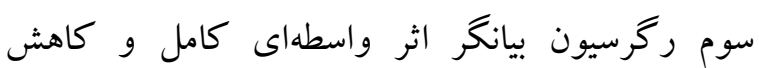

\footnotetext{
1- Baron, R. M.

2- Kenny, D. A.
} 
عينى " را مىسنجد. نمره گذارى اين مقياس بر اساس

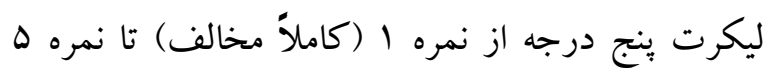

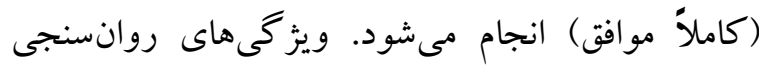

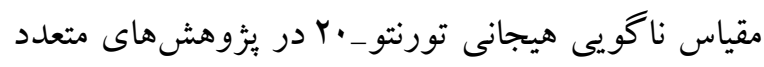

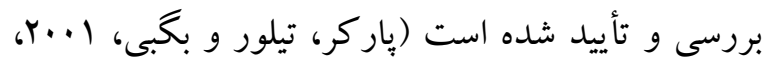

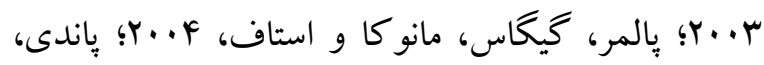

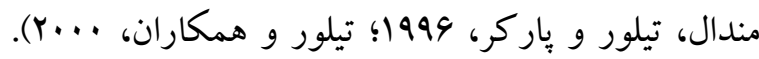

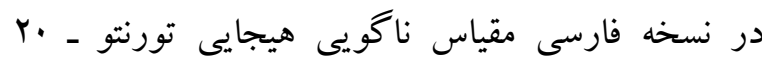

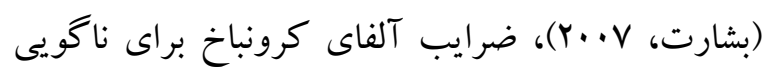
هيجانى كل و سه زيرمقياس دشوارى در شناسايى احساسها، دشوارى در توصيف احساسها و تفكر عينى

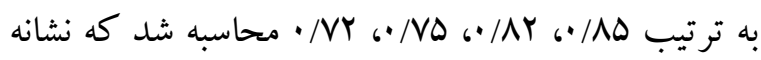
همسانى درونى ه خوب مقياس است. نتايج ضرايب همبستكى بيرسون نشان مىدهد كه بين نمره آزمودنىها

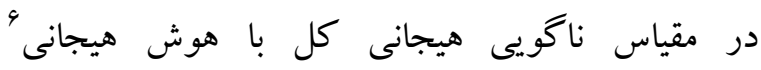

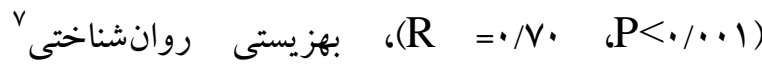

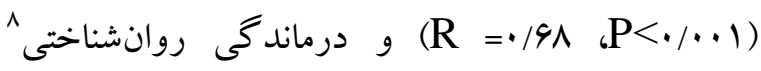
همبستگى معنادار وجود دارد. (R =•/FF $\mathrm{P}<\cdot / \cdot 1)$ نتايج تحليل عاملى تأييدى نيز وجود سه عامل دشوارى در شناسايى احساسها، دشوارى در توصيف احساسها و تفكر عينى را در نسخه فارسى مقياس ناكويى هيجانى تورنتو - ·r تأييد كردهاند (بشارت، rarاן). در اين

$$
\text { يثزوهش آلفاى كرونباخ VV/ • به دست آمد. }
$$

مقياس دشوارى در تنظيم هيجان ': اين ابزار وب مادّهاى

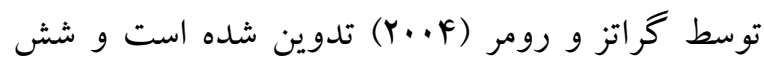

${ }^{4}$ - Externally oriented thinking (EOT)

5 - Internal consistency

6 - Emotional intelligence

7- Psychological well-being

${ }^{8}$ - Psychological distress

9 - Confirmatory factor analysis

${ }^{10}$ - Difficulties in Emotion Regulation Scale (DERS)
هيجانى (Vبارت) را در سه زيرمقياس اجتناب تجربهاى، يذيرش و انعطافنايذيرى روانشناختى فرد مىسنجد. نمره گذارى يرسشنامه يُّيرش و عمل - نسخه دوم بر

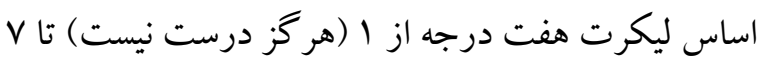
(هميشه درست است) انجام مىشود. در اين پرسشنامه، نمرههاى بالا نشان دهندة اجتناب تجربهاى و انعطافنايذيرى روانشناختى بيشتر و نمرههاى بايين، نشانه يذيرش و عمل بيشتر است. ويز گیىهاى روانسنجى نسخه اصلى بدين شرح است: نتايج YN19 شركت كننده در طول 9 نمونه نشان داد كه اين ابزار روايى و اعتبارسازى رضايتبخشى دارد. ميانخين ضريب آلفاى

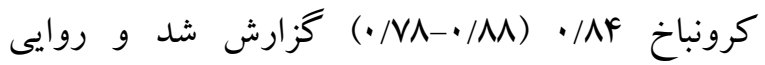

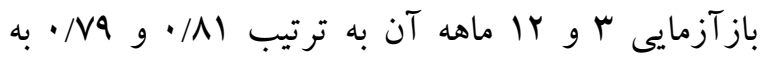

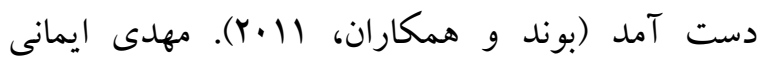
(هوسו) در ايران به بررسى اعتبار و روايى اين برسشنامه يرداخت. نتايج اعتبار (همسانى درونى) اين برسشنامه را به

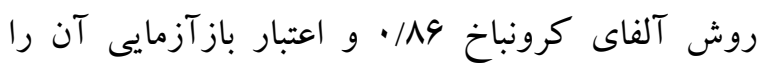

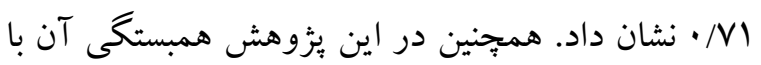

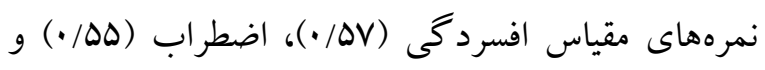
استرس (101/•) روايى همخرا و همبستكى با نمرههاى يرسشنامه سلامت عمومى (4 (4/•)، روايى واكراى يرسشنامه را نشان داد. در اين يزوهش آلفاى كرونباخ

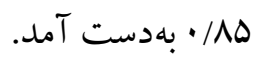

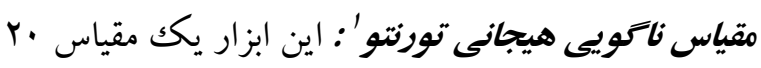

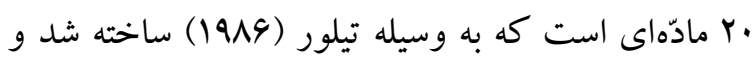
توسط بخبى و همكاران (1994) مورد تجديد نظر قرار كرفت. اين ابزار سه زيرمقياس دشوارى در شناسايى احساسها؟، دشوارى در توصيف احساسها؟ و تفكر دريك

\footnotetext{
'- Toronto Alexithymia Scale-20 (TAS-20)

${ }^{2}$ - Difficulty in identifying feelings (DIF)

${ }^{3}$ - Difficulty in describing feelings (DDF)
} 
اين يُزوهش روى ·9 نفر از بيماران مبتلا به افسردگى

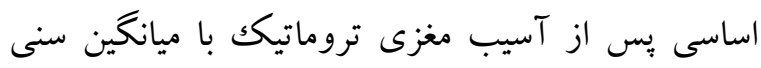

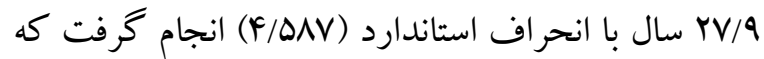
از لحاظ جنس، هان نفر از آنها مردو ها نفر زن بودند. از

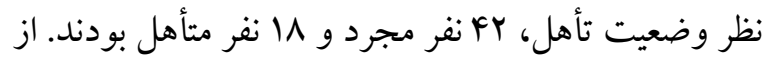
نظر سطح تحصيلات، ·r نفر در حد سيكل، MF نفر دييلم، F نفر فوق دييلم و Y نفر كارشناسى بودند. علاوه بر

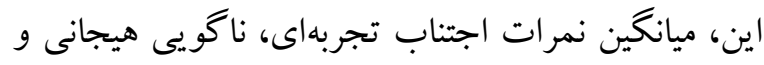
تنظيم هيجان به ترتيب هاr/N" استانداردهاى اين متغيرها به ترتيب ه/A

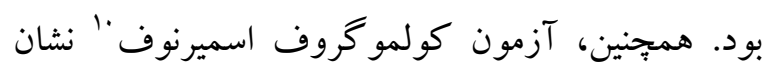

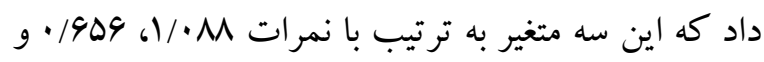
1911/ • داراى توزيع نرمال هستند (ه •/ • (P>). براى بررسى رابطه بين اجتناب تجربهاى، ناگويى هيجانى و تنظيم هيجان از آزمون همبستخى بيرسون استفاده شد بردي

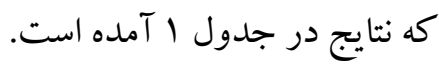

زيرمقياس، عدم يذيرش بِاسخهاى هيجانى'، دشوارى در

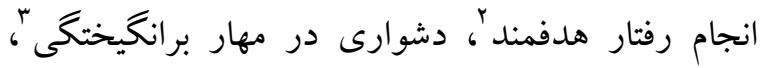

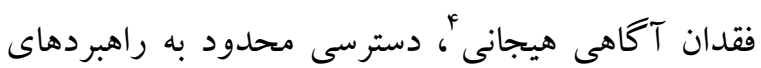
تنظيم هيجانه و عدم وضوح هيجانى " را مىسنجد. نمره گذارى اين مقياس بر اساس ليكرت ينج درجه از ا(تقريباً هر گز) تا ها (تقريباً هميشه) انجام مىشود. نتايج يثزوهش كراتز و رومر (F..F) نشان داد كه اين مقياس از همسانى درونى بالايى (سو/•) برخوردار است. هر شش زيرمقياس برسشنامه آلفاى كرونباخ بالاى •A/· دارند. همجينين همبستخى معنادارى با مقياس انتظار تعميم يافته

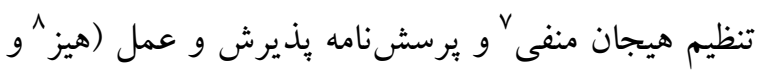

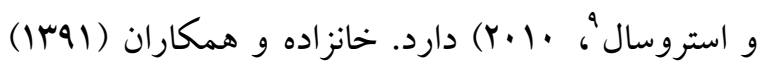
در ايران به بررسى اعتبار و روايى اين مقياس برداختند. نتايج تحليل عاملى اين مقياس، مطابق با مقياس اصلى، 9 زيرمقياس را نشان داد. همجنين در اين يزوهش،

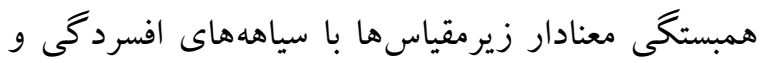
اضطراب بك، روايى همخراى اين مقياس را نشان داد. نتايج حاصل از بررسى اعتبار اين مقياس نيز نشان داد كه

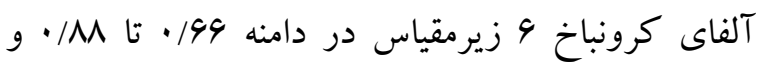

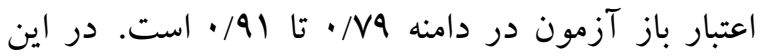
يُزوهش آلفاى كرونباخ هر شش زيرمقياس برسشنامه در دامنه 191• تا •9/9 • به دست آمد.

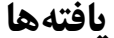

\footnotetext{
1- Nonacceptance of negative emotions

2 - Difficulties engaging in goal-directed behaviors

3 - Difficulties in controlling impulsive behaviors

${ }^{4}$ - Lack of emotional awareness

5 - Limited access to effective emotion regulation strategies

${ }^{6}$ - Lack of emotional clarity

7- Negative Mood Regulation expectancy questionnaire (NMR)

${ }^{8}$ - Hayes, S. C

${ }^{9}$ - Strosahl, K. D. 


\begin{tabular}{|c|c|c|c|}
\hline دشوارى در تنظيم هيجان & ناتويى هيجانى & اجتناب تجربهاى & متغير ها \\
\hline & & 1 & اجتناب تجربهاى \\
\hline & 1 & $\cdot / F Y D^{* * *}$ & ناتويى هيجانى \\
\hline 1 & $\cdot 199 V^{*}$ & $\cdot / 0 \cdot F^{*}$ & دشوارى در تنظيم هيجان \\
\hline
\end{tabular}

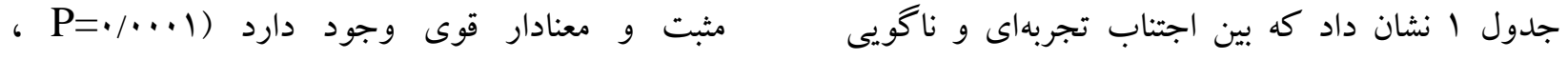
•) (r=-199V هيجانى همبستگى مثبت و معنادار متوسطى وجود دارد است هم خطى ساده وجود ندارد. يارامتر تحمل نيز وجود

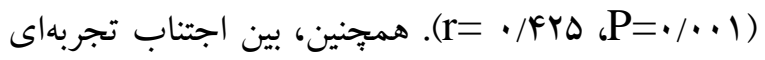
هم خطى جند كانه را نفى كرد (F) tolerance و دشوارى در تنظيم هيجان همبستكى مثبت و معنادار r VIF> > F

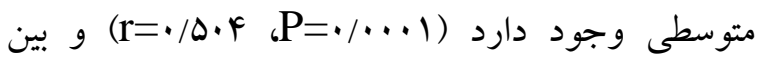
نشان داده شده است. ناكويى هيجانى و دشوارى در تنظيم هيجان نيز همبستخى

\begin{tabular}{|c|c|c|c|c|c|c|c|c|c|c|}
\hline \multicolumn{2}{|c|}{ آزمون سوبل } & \multicolumn{2}{|c|}{ تحليل واريانس } & \multicolumn{4}{|c|}{ آزمون تى } & \multirow[t]{3}{*}{ ملاكs } & \multirow[t]{3}{*}{ بيشبين } & \multirow[t]{3}{*}{ كام } \\
\hline سطح & $\mathrm{Z}$ & سطح & Fاره F F F & ضريب & سطح & $\mathrm{t}$ & ضريب بتاى & & & \\
\hline \multirow[t]{3}{*}{ معنادارى } & & معنادارى & & تعيين & معنادارى & & استاندارد & & & \\
\hline & & $\cdot / \cdot 1^{* * *}$ & $|Y / \Lambda \cdot|$ & $\cdot / 111$ & $\cdot / \cdot 1^{*}$ & $r / \Delta V \wedge$ & . /FTD & اجتناب تجربهاى & هاكويى & 1 \\
\hline & & $\cdot /\left.\cdots\right|^{* * *}$ & $\Delta F / V \Delta I$ & $\cdot / 4 \wedge 9$ & $\cdot /\left.\cdots\right|^{* * *}$ & $V / r 99$ & $.199 \mathrm{~V}$ & دشوارى در تنظيم & هاتويى & r \\
\hline \multirow[t]{2}{*}{$\cdot / \cdot r V^{* * *}$} & $r / \cdot V q$ & $\cdot(\cdots)^{* * *}$ & Tr/rol & . $/ \Delta \mu^{\prime}$ & $\cdot / \cdot 1 r^{* * * *}$ & $r / \Delta \Delta \Delta$ & - /YAF & دشوارى در تنظيم & تجربهاى & $r$ \\
\hline & & & & & $\cdot / \cdots l^{* * *}$ & $\Delta / Q R T$ & $\cdot / 0 \wedge 9$ & & هاتويى & \\
\hline
\end{tabular}

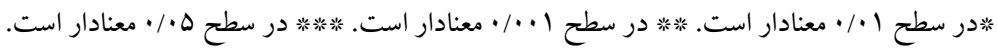

استاندارد بين ناكويى هيجانى و اجتناب تجربهاى نيز

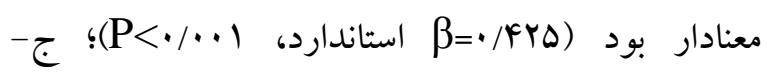
همجنين، اجتناب تجربهاى يس از ورود همزمان با بان ناكويى هيجانى، اثر معنادارى بر تنظيم هيجان داشت

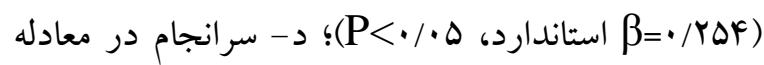
سوم رگرسيون، معنادارى ضريب بتاى استاندارد مربوط به
تحليل رگرسيون سلسله مراتبى در جدول Y نشان داد كه اجتناب تجربهاى در رابطه بين ناگويى هيجانى و دشوارى در تنظيم هيجان، نقش واسطهاى دارد و جهار شرط بارون و كنى محقق شد: الف- ضريب بتاى استاندارد بين ناكويى هيجانى و دشوارى در تنظيم هيجان معنادار بود

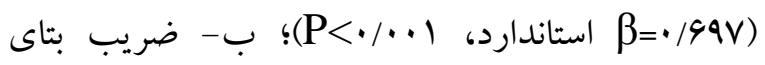


جدول r مشخص است، آزمون تحليل واريانس معنادارى هر سه گام را نشان داده است. نمودار ا طبق دادههاى جدول r، نقش واسطهاى اجتناب تجربهاى را در رابطه بين ناكويى هيجانى و تنظيم هيجان را نشان مىدهد كه در
رابطه ناگويى هيجانى و دشوارى در تنظيم هيجان كاهش معنادار نشان داد كه اين حاكى از اثر واسطهاى جزئى

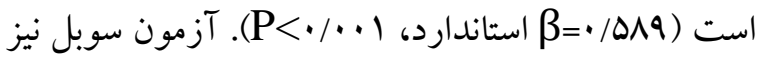
معنادارى اثر واسطهاى اجتناب تجربهاى را نشان داد

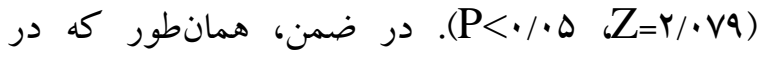
(1): اثر كل ناكويى هيجانى بر تنظيم هيجان (Y): اثر ناكويى هيجانى بر تنظيم هيجان با كنترل اجتناب تجربهاى ( ) (Y): اثر اجتناب تجربهاى بر تنظيم هيجان

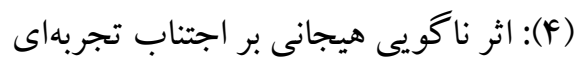
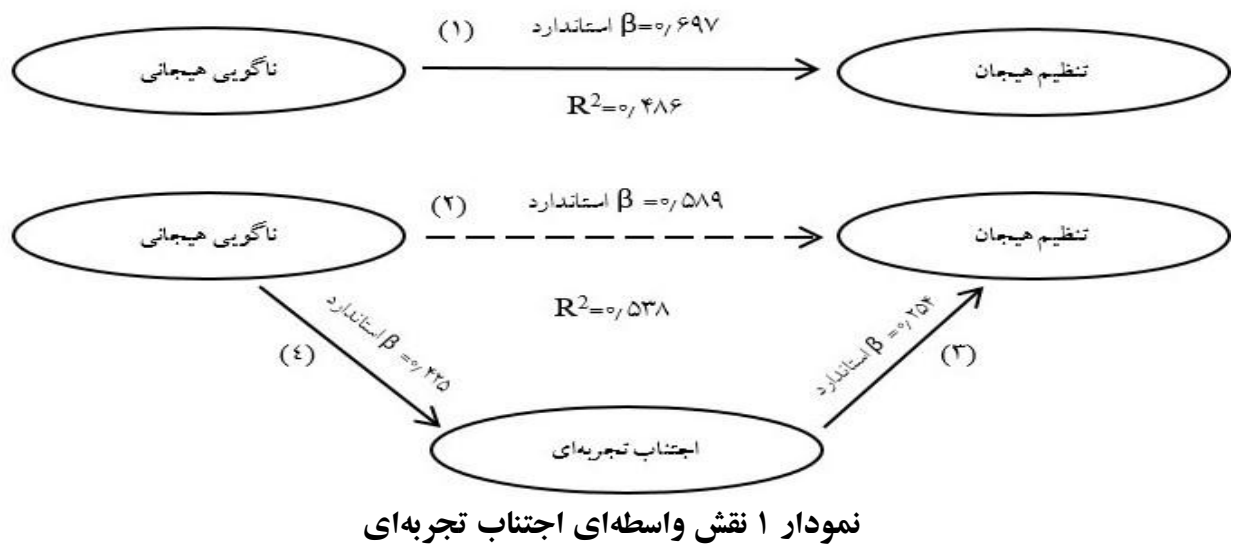

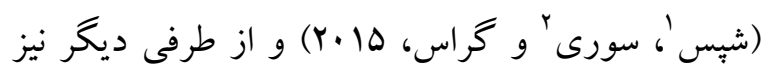
اين متغير با ناكويى هيجانى و به خصوص با زيرمقياس هدف از اين يُزوهش بررسى نقش واسطهاى اجتناب

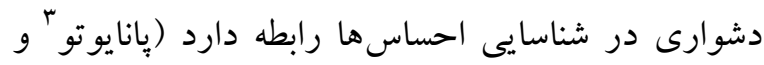
تجربهاى در رابطه بين ناكويى هيجانى و تنظيم هيجان در

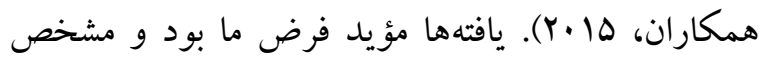
بيماران مبتلا به افسردگى اساسى يس از آسيب مغزى شد كه اجتناب تجربهاى در ارتباط بين ناگويى هيجانى و مانو

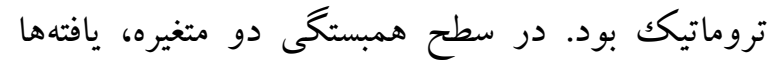
تنظيم هيجان، نقش واسطهاى جزئى ايفا مى كند. بدين نشان دادند كه بين ناگويى هيجانى، تنظيم هيجان و معنى كه يس از ورود متغير واسطه، معنادارى ارتباط بين اجتناب تجربهاى ارتباط معنادار وجود دارد. در سطح جند دو متغير مستقل و وابسته به طور كامل از دست نرفته و متغيره، فرض ما اين بود كه اجتناب تجربهاى مىتواند در فقط كاهش معنادار داشته كه نشانه اثر واسطهاى جزئى رابطه دو متغير ديخر اين بزوهش، نقش واسطهاى ايفا است. اين يافته با بثزوهش ونتا و همكاران (Y (Y)

3. Panayiotou, G. كند؛ جرا كه از طرفى ارتباط اجتناب تجربهاى با دشوارى در طبقات مشخصى از تنظيم هيجان نشان داده شده است 
بيماران مبتلا به افسردگى اساسى يس از آسيب مغزى كاهش دهند، تأثير ناگويى هيجانى كه در اين بيماران شيوع بسيار بالايى (نيومن، Y.|r) دارد بر دشوارى در تنظيم هيجان كه اين نيز در اين بيماران رايج و با دامنه وسيعى از سيميتومها مرتبط است (ساوسايدز، IV) و (Y) و فى نفسه در بِاتولوزى افسردگى نقش قدرتمندى دارد

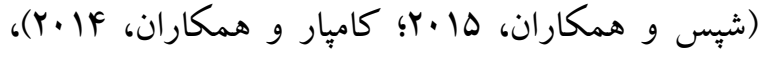
كاهش مى يابد. در واقع، افر ادى كه دجار ناكويى هيجانى هستند به دليل داشتن دشوارى در شناسايى هيجانهايشان، به جاى تنظيم هيجان متمر كز بر بيشايند، از تنظيم هيجان متمركز بر بِاسخ كه به يسايند اشاره دارد، بهره مي برند. اين نوع تنظيم هيجان در واقع تنظيم بيامدهاى هيجان و

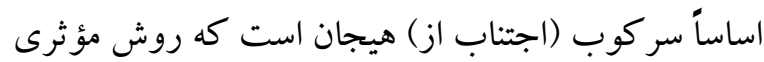
براى تنظيم هيجانهاى منفى نيست؛ بنابراين، احتمالاً ناكويى هيجانى به صورت نقص در تنظيم هيجان بر سطح

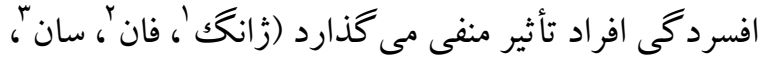

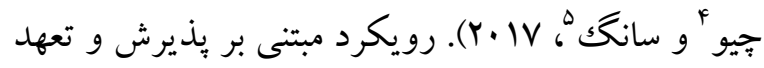
يكك ديدگاه درمانى است كه با تأكيد بر بذيرش تجربهاى، فرايندى در مقابل اجتناب تجربهاى (هيز و استروسال، · ·(Y)، يعنى عدم تلاش براى تغيير يا كنترل تجربيات بد درونى، به دنبال ايجاد انعطافيذيرى روانشناختى بيشتر است (بارانوف و همكاران، 19.ب).

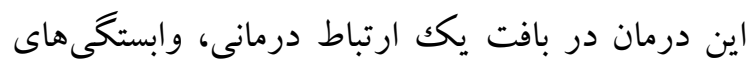
مستقيم و فرايندهاى كلامى غيرمستقيم را به كار مى كيرد تا بهطور تجربى از طريق بذيرش، نا همجوشى، ايجاد يكك حس فرا تجربى از خود، ارتباط با لحظه اكنون، ارزشها و ساختن الكوهايى از اقدامهاى متعهدانه مرتبط

${ }^{1}$ - Zhang, $\mathrm{H}$.

2- Fan, Q

${ }^{3}$ - Sun, Y.

4- Qiu, J.

5 - Song, L.
هماهنگ است كه در رابطه بين ناكويى هيجانى و تنظيم هيجان نوجوانان، نقش واسطهاى جزئى را براى اجتناب تجربهاى نشان دادند (ونتا و همكاران، Y (Y). اجتناب تجربهاى (متغير واسطهاى) مكانيزمى است كه ناكويى لهري هيجانى از طريق آن بر روى تنظيم هيجان تأثير مى گذارد

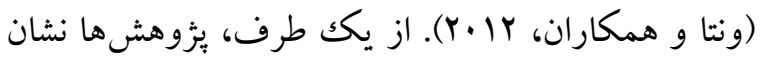
دادهاند كه بين ناگويى هيجانى و تنظيم هيجان رابطه وابستخى متقابل وجود دارد؛ يعنى اگرجه تنظيم هيجان و ناكويى هيجانى دو سازه مستقل از هم هستند، بين برخى از مؤلفههاى اين دو سازه ارتباط و بين برخى از مؤلفههاى

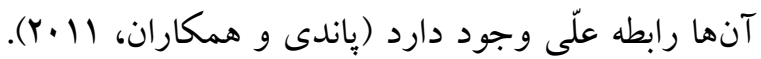
از طرفى ديخر، اگر اجتناب تجربهاى ناشى از نوعى بيشارزيابى در هزينه وضعيتهاى هيجانى تعريف شود، در اين صورت، دشوارى در عنصر ارزيابى مربوط به طبقه شناسايى هيجان كه در ئزوششاى نظرى تنظيم هيجان عنوان شده است (شيس و همكاران، ها··r) را مطرح مى كند و در عين حال، مشخص شده است كه اجتناب تجربهاى با مفهوم دشوارى در شناسايى احساسها مطرح در ناكويى هيجانى ارتباط دارد بدين معنا كه افراد داراى دشوارى در شناسايى احساسها، ممكن است اساساً در حال تلاش براى اجتناب از تجربه احساسها باشند

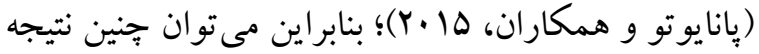
كرفت كه در بعد شناسايى، اجتناب تجربهاى احتمالاً وضعيت بالينى مشتركى بين ناكويى هيجانى و تنظيم هيجان است و اين امر مىتواند يافته اين يُوهش را در مورد نقش واسطهاى اجتناب تجربهاى توجيه نمايد؛ يعنى با حضور اجتناب تجربهاى تأثير ناكويى هيجانى بر تنظيم

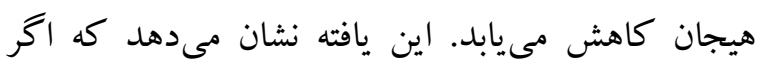

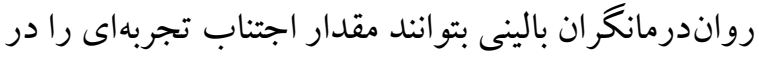


يس از آسيب مغزى گزينه مناسبى باشد البته اغلب

رواندرمانىهاى امروزى به نحوى اجتناب تجربهاى را

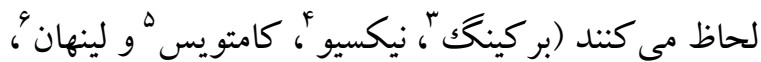

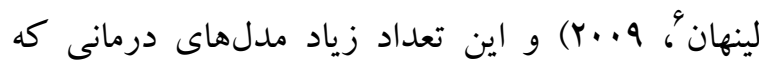
اجتناب تجربهاى و مشكلات هيجانى مرتبط با آن را هدف قرار مىدهند، اهميت بالينى اجتناب تجربهاى را نشان مىدهد (ونتا و همكاران، Y I (Y). به طور خلاصه، يافتهاى اين يُوهش به دركك نظرى اين سه وضعيت بالينى كمكك مى كند. همجينين رويكرد بالينى بيماران مذكور را يارى مىدهد. از آنجايى كه نمونه اين يُزوهش را سنين \| تا لها سال تشكيل دادند، مىبايست تعميم نتايج با احتياط صورت بـيرد.

\section{سياسگز ارى}

از همكارى تمام مسئولان بيمارستان شهيد بهشتى كاشان

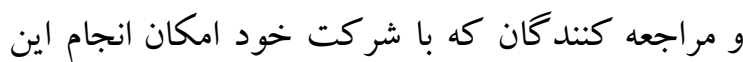
يُزوهش را فراهم كردند؛ سِاسگز اريم.

\section{References}

Aboulafia-Brakha T, Allain P, \& Ptak R. (2016). Emotion regulation after traumatic brain injury: distinct pattems of sympathetic activity during anger expression and recognition. The Journal of Head Trauma Rehabilitation, 31(3), 21-31.

Ashman TA, Gordon WA, Cantor JB, \& Hibbard MR. (2006). Neurobehavioral consequences of traumatic brain injury. Mt Sinai J Med, 73(7), 999-1005.

Bach PA, Moran DJ, \& Hayes SC. (2008). ACT in practice: case conceptualization in acceptance

${ }^{3}$ - Berking, $\mathrm{M}$.

4- Neacsiu, A.

5 - Comtois, K. A.

6. Linehan, M. M.
با اين ارزشها، انعطافيذيرى روانشناختى بيشترى در

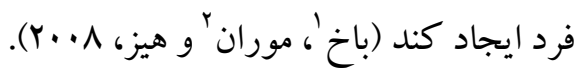
اين يزوهش حداقل دو محدوديت عمده دارد: اولاً طرح

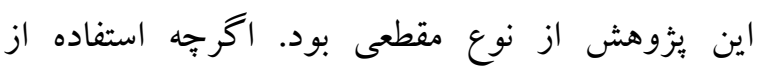
روشهاى آمارى مناسب، شواهدى درباره نقش واسطهاى اجتناب تجربهاى در رابطه بين ناكويى هيجانى و تنظيم هيجان در بيماران مبتلا به افسردگى اساسى بس از آسيب مغزى تروماتيكك به دست مىدهد، لكن بدون يكك طرح طولى نمى توان روابط علت و معلولى بين اين سه وضعيت

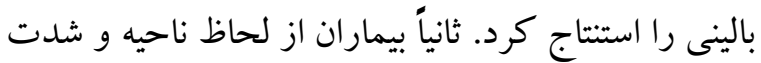
آسيب به سر متمايز نشده بودند. لوب يا لوب های دركير آسيب و همجينين آسيبهاى خفيف، متوسط و شديد سر مىتواند تابلوى بالينى بيمار را تحت تأثير قرار دهند. ييشنهاد مى شود كه اين بثزوهش با حجم نمونه بيشتر، روشهاى آمارى مدلسازى مانند تحليل مسير و معادلات ساختارى و طرحهاى يُزوهشى طولى و آزمايشى تكرار شود تا از اين طريق مدل نظرى منسجمترى در اين زمينه تدوين شود و روابط علت معلولى آشكار كردد.

\section{نتيجه كيرى} با توجه به يافته هاى بثوهش شايد بتوان با تغيير در اجتناب

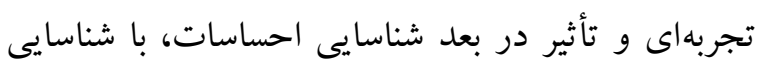
بهتر احساسات تأثير ناكويى هيجان را كاهش داده و به جاى تنظيم هيجان متمر كز بر بِ بـ آيند يا پِاسخ، از تنظيم هيجان متمر كز بر بيش آيند بهره برد كه در نتيجه ديخر از تنظيم متمر كز بر پياسخ كه در واقع سركوب هيجان است استفاده نخواهد شد. به نظر مىرسد درمان مبتنى بر

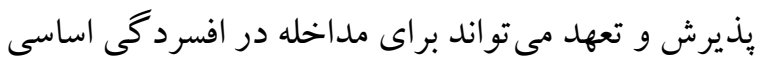

\footnotetext{
1- Bach, P. A.
}

${ }^{2}$ - Moran, D. J. 
\& commitment therapy. oakland, CA: New Harbinger.

Bagby RM, \& Taylor GJ. (1997). Affect dysregulation and alexithymia. In G.J. Taylor, R. M. Bagby, J. D. A., Parker (Eds), Disorders of Affect Regulation: Alexithymia in Medical and Psychatric Illness (pp. 26-45). Cambridge: University Press.

Bagby RM, Parker JD, \& Taylor GJ. (1994). The twenty-item toronto alexithymia scale-I. item selection and cross-validation of the factor structure. Journal of Psychosomatic Research, 38(1), 23-32.

Baranoff JA, Hanrahan SJ, Burke AL, \& Connor JP. (2016). Changes in acceptance in a lowintensity, group-based acceptance and commitment therapy (ACT) chronic pain intervention. Intemational Joumal of Behavioral Medicine, 23(1), 30-38.

Baron RM, Kenny DA. (1986). The moderatormediator variable distinction in social psychological research: conceptual, strategic, and statistical considerations. Joumal of personality and social psychology, 51(6), 1173-1182.

Berking M, Neacsiu A, Comtois KA, Linehan MM. (2009). The impact of experiential avoidance on the reduction of depression in treatment for borderline personality disorder. Behav Res Ther, 47(8), 663-670.

Besharat MA. (2007). Reliability and factorial validity of a farsi version of the 20-item toronto alexithymia scale with a sample of iranian students. Psychological reports, 101(1), 209220. [Persian].

Bombardier CH, Fann JR, Temkin NR, Esselman PC, Barber J, \& Dikmen SS. (2010). Rates of major depressive disorder and clinical outcomes following traumatic brain injury. Jama, 303(19), 1938-1945.

Bond FW, Hayes SC, Baer RA, Carpenter KM, Guenole N, Orcutt HK, et al. (2011). Preliminary psychometric properties of the acceptance and action questionnaire-II: a revised measure of psychological inflexibility and experiential avoidance. Behav Ther, 42(4), 676-688.

Compare A, Zarbo C, Shonin E, Gordon W, \& Marconi C. (2014). Emotional regulation and depression: a potential mediator between heart and mind. Cardiovascular Psychiatry and Neurology, 324-374.

Fietz J, Valencia N, Silani G. (2018). Alexithymia and autistic traits as possible predictors for traits related to depression, anxiety, and stress: A multivariate statistical approach. J Eval Clin Pract, 24(4), 901-908.

First M, Williams J, Karg R, \& Spitzer R. (2015). Structured clinical interview for DSM-5 disorders, clinician version (SCID-5-CV). arlington, VA: American Psychiatric Association.

Frieden T, Houry D, \& Baldwin G. (2015). Report to congress on traumatic brain injury in the united states: epidemiology and rehabilitation. Atlanta, GA: National Center for Injury Prevention and Control; Division of Unintentional Injury Prevention.

Gratz KL, \& Roemer L. (2004). Multidimensional assessment of emotion regulation and dysregulation: development, factor structure, and initial validation of the difficulties in emotion regulation scale. Joumal of Psychopathology and Behavioral Assessment, 26(1), 41-54.

Gross JJ. (1998). The emerging field of emotion regulation: An interative review. Review of General Psychology, 2(3), 271-299.

Hayes SC, \& Strosahl KD. (2010). A practical guide to acceptance and commitment therapy. New York: Springer science and business media Inc.

Hemming L, Haddock G, Shaw J, Pratt D. (2019). Alexithymia and Its Associations With Depression, Suicidality, and Aggression: An Overview of the Literature. Front Psychiatry.

Imani M. (2016). Factor Structure of psychological flexicurity questionnaire in students. Joumal of Educational and Leaming Studies, 8(1), 162181. [Persian]. 
Juengst SB, Kumar RG, \& Wagner AK. (2017). A narrative literature review of depression following traumatic brain injury: prevalence, impact, and management challenges. Psychology Research and Behavior Management, 10, 175-185.

Khanzadeh M, Saidiyan M, Hosseinchary M, Edrissi F. (2012). Factor structure and psychometric properties of Difficulties in Emotion Regulation scale. Joumal of behavioral Sciences, 6(1), 87-96. [Persian].

Mauri MC, Paletta S, Colasanti A, Miserocchi G, \& Altamura AC. (2014). Clinical and neuropsychological correlates of major depression following post-traumatic brain injury, a prospective study. Asian joumal of Psychiatry, 12,118-124.

Neumann D. (2017). Treatments for emotional issues after traumatic brain injury. The Joumal of Head Trauma Rehabilitation, 32(5), 283-285.

Panayiotou G, Leonidou C, Constantinou E, Hart J, Rinehart KL, Sy JT, et al. (2015). Do alexithymic individuals avoid their feelings? Experiential avoidance mediates the association between alexithymia, psychosomatic, and depressive symptoms in a community and a clinical sample. Comprehensive psychiatry, 56, 206-216.

Pandey R, Saxena P, \& Dubey A. (2011). Emotion regulation difficulties in alexithymia and mental health. Europe's Joumal of Psychology, 7(4), 604-623.

Rao V, Mielke M, Xu X, Smith GS, McCann UD, Bergey A, \& et al. (2012). Diffusion tensor imaging atlas-based analyses in major depression after mild traumatic brain injury. The Joumal of Neuropsychiatry and Clinical Neurosciences, 24(3), 309-315.

Sheppes G, Suri G, Gross JJ. (2015). Emotion regulation and psychopathology. Annual review of clinical psychology, 11, 379-405.

Taylor GJ, Bagby RM, \& Parker JDA. (1997). Disorders of affect regulation: Alexithymia in medical and psychiatric illness. Cambridge: Cambridge University Press.
Taylor GJ, Parker JDA, Bagby RM, \& Acklin MW. (1992). Alexithymia and somatic complaints in psychiatric out-patients. Joumal of Psychosomatic Research, 36, 417-424.

Trent ES, Viana AG, Raines EM, Woodward EC, Storch EA, Zvolensky MJ. (2019). Parental threats and adolescent depression: The role of emotion dysregulation. Psychiatry Res, 5(276), 18-24.

Tsaousides T, Spinser L, Kajankova M, Guetta G, Gordon W, \& O'Cannor KD. (2017). Improving emotion regulation following webbased group intervention for individuals with traumatic brain injury. Joumal of Head Trauma Rehabil, 32(5), 354-365.

Venta A, Hart J, \& Sharp C. (2012). The relation between experiential avoidance, alexithymia and emotion regulation in inpatient adolescents. Clinical Child Psychology and Psychiatry, 18(3), 398-410.

Yohannes AM. (2016). Depression in survival following acute infection. Joumal of psychosomatic research, 90(2), 82-96.

Zhang H, Fan Q, Sun Y, Qiu J, \& Song L. (2017). A Study of the characteristics of alexithymia and emotion regulation in patients with depression. Shanghai Archives of Psychiatry, 29(2), 95103. 